\title{
An investigation on factors influencing on human resources productivity
}

\author{
Masoumeh Seifi Divkolaii*
}

Member of Young Researchers Club of Qaemshahr,PhD Student in Media management, Imam Reza International University, Mashhad, Iran

\section{CH R O N I C L E}

\section{Article history:}

Received December 28, 2013

Accepted 28 March 2014

Available online

April 102014

Keywords:

Productivity

Human resource productivity

Delphi

AHP Techniques \begin{abstract}
A B S T R A C T
Human resources development is one of the most important components of any organization and detecting important factors influencing on human resources management plays essential role on the success of the firms. In this paper, we present an empirical investigation to determine different factors influencing productivity of human resources of Islamic Republic of Iran Broadcasting (IRIB) in province of Mazandaran, Iran. The study uses analytical hierarchy process (AHP) to rank 17 important factors and determines that personal characteristics were the most important factors followed by management related factors and environmental factors. In terms of personal characteristics, job satisfaction plays essential role on human resources development. In terms of managerial factors, paying attention on continuous job improvement by receiving appropriate training is the most important factor followed by welfare facilities for employees and using a system of reward/punishment in organization. Finally, in terms of environmental factors, occupational safety is number one priority followed by organizational rules and regulations.
\end{abstract}

\section{Introduction}

Efforts to improve the efficient use of different resources such as human force, capital, materials, energy and information, is the primary objective of all economic organizations. The existence of suitable organizational structure, work procedures, healthy equipment and tools, balanced work environment as well as qualified and competent human force are required to achieve optimal productivity (Zheng \& Sun, 2011; Beerkens, 2013). Employee's participation in conscious and deliberate efforts with their work discipline influences on the productivity. The spirit of improving the productivity culture should be blown to the body of firms where the workforces form its core. According to Chlivickas (2014), in order to build effective public service, it is essential to systematically improve human resource system, through innovations since it could guarantee success in pursuing objectives and priorities in the state management and for improvement of public administration system.

*Corresponding author.

E-mail addresses: anabavichashmi2003@gmail.com (S. A. Nabavi Chashmi) 
Allameh et al. (2012) studied the effect of Information Communication Technology (ICT) dimensions on work force productivity of Mobarekeh steel complexion in Isfahan. They reported that ICT dimensions including Information technology, Management Information System, Internet, Office automation and Internet influenced human resource productivity of Mobarekeh Steel complex in Isfahan. Bloom and Reenen (2011) investigated the relationship between Human Resource Management (HRM) and productivity. In this survey, HRM includes incentive pay, matching (hiring and firing) and work organization (e.g. teams, autonomy). They placed HRM within the literature on management practices and productivity and studied some facts on levels and trends of both HRM and productivity and the main economic theories of HRM. They looked at some of the determinants of HRM including risk, competition, ownership and regulation. Göbel and Zwick (2013) investigated the relationship between five specific HRM for old employees and the relative productivity of some old employees. They reported that the relative productivity contributions of old workers were substantially higher in establishments, which provided either specific equipment of work places or age-specific jobs for old workers. In establishments that use mixed-age working teams the relative productivity contributions of old and of young employees were substantially higher than in establishments without this measure.

Slavich et al. (2013) studied that brand units' images could play essential role between HRM practices and employee internal and external turnover. They reported that the existence of imbalanced and differently attractive brand units' images could weaken or remove the effectiveness of firm's HRM practices in keeping internal and external turnover rates low. They also shed light on the debate regarding the use of HRM practices in multi-brand firms, especially in industries where both the brand and the product maintained a highly-symbolic content. They suggested that brand units with less prestigious images could compensate for their lower attractiveness with specific brand unit HRM practices to absorb and to keep their employees. Jiang et al. (2012) reviewed different components of human resource systems and delineated how the parts of human resource systems could work together to impact employee performance. Marco-Lajara and Úbeda-García (2013) identified the specific human resource practices implemented by hotel industry by considering number of employees, nationality and sex and to human resource strategies including recruitment, hiring and training strategies. They reported that a hard human resource method prevails and that hotels applied the same human resource strategies regardless of their category or competitive strategy.

\section{The proposed study}

Islamic Republic of Iran Broadcasting (IRIB) is considered as a giant Iranian corporation in control of radio and television, which is among the largest media organizations in Asia and Pacific region, and a regular member of Asia-Pacific Broadcasting Union. One of the most important issues on development of IRIB organization is to increase human resources' efficiencies. To identify the influencing factors on human resource productivity (non-faculty members) in IRIB in province of Mazandaran, Iran, the study uses library studies while using Delphi method in two stages as well as getting experts' feedbacks in the first stage. Then, obtained results of the survey from experts and library studies were compared and the confluence point by adding frequency of $50 \%$ to up were selected. Finally, 17 variables including three major principles including managerial, interpersonal and environmental was recognized.

\section{The results}

In this survey, we have used analytical hierarchy process (AHP) to rank different factors by making pairwise comparisons. Fig. 1 shows details of our factors. The implementation of AHP applies geometric mean to provide the mean scores given to different factors and the entire model has been applied on MATLAB software package. Table 1 demonstrates the results of our investigation. 


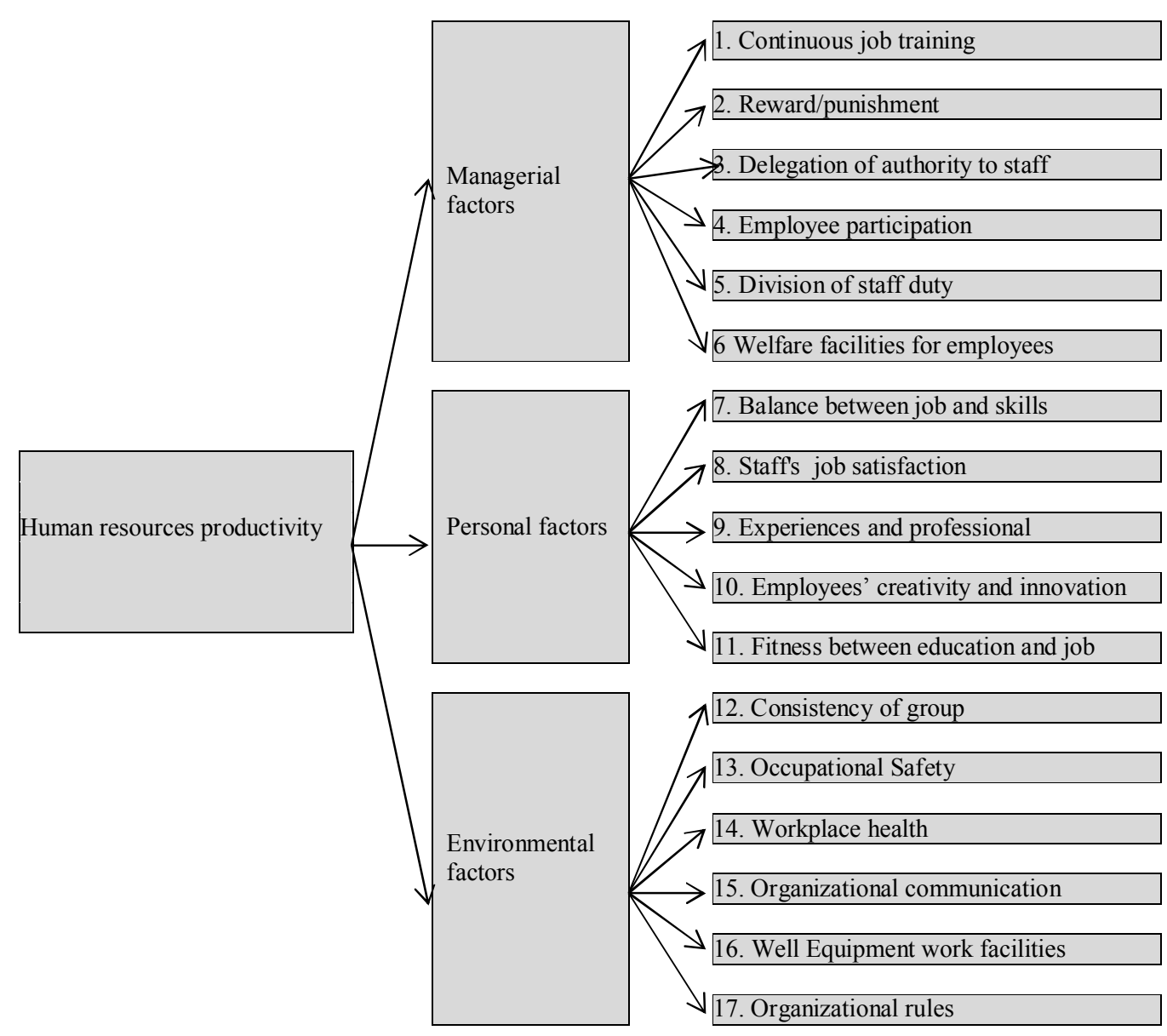

Fig. 1. The hierarchy of the proposed study

\section{Table 1}

The final weight and rank the importance of each factor

\begin{tabular}{|c|c|c|c|c|c|}
\hline Main factor & Of 17 -fold & The final weight & Ranking each factor & Mean & Rank \\
\hline \multirow{6}{*}{$\begin{array}{l}\text { Managerial } \\
\text { factors }\end{array}$} & 1. Paying more attention to continuous job training & 0.0559 & 6 & & \\
\hline & 2. Using a system of reward/punishment in organization & 0.0478 & 9 & & \\
\hline & 3. Delegation of authority to staff & 0.0251 & 11 & 9.83 & 2 \\
\hline & 4. Employee participation in organizational decision making & 0.0223 & 14 & & \\
\hline & 5. Division of staff duty & 0.0239 & 12 & & \\
\hline & 6. Providing welfare facilities for employees & 0.0543 & 7 & & \\
\hline \multirow{5}{*}{$\begin{array}{l}\text { Personal } \\
\text { factors }\end{array}$} & 7. Balance between job and technical skills & 0.1268 & 3 & & \\
\hline & 8. Staff's job satisfaction & 0.1657 & 1 & & \\
\hline & 9. Experiences and professional & 0.0439 & 10 & 5.20 & 1 \\
\hline & 10. Employees' creativity and innovation & 0.0490 & 8 & & \\
\hline & 11. Fitness between education and job & 0.1183 & 4 & & \\
\hline \multirow{6}{*}{$\begin{array}{l}\text { Environmental } \\
\text { factors }\end{array}$} & 12. Consistency of group & 0.0225 & 13 & & \\
\hline & 13. Occupational Safety & 0.1391 & 2 & & \\
\hline & 14. Workplace health & 0.0166 & 15 & 11.33 & 3 \\
\hline & 15. Organizational communication & 0.0142 & 17 & & \\
\hline & 16. Well Equipment work facilities & 0.0155 & 16 & & \\
\hline & 17. Organizational rules & 0.0591 & 5 & & \\
\hline
\end{tabular}

The implementation of AHP method requires a good consistency among pairwise comparisons. Table 2 shows details of our computations on consistency index and consistency ratios. 
Table 2

The calculated rate of incompatibility

$\begin{array}{cc}\text { (Largest value) } \lambda_{\max } & 17.7078 \\ (\text { Consistency index }) \mathrm{CI}=(\lambda \text { max-n }) / \mathrm{n}-1 & 0.0442 \\ (\text { Consistency ratio }) \mathrm{CR}=\mathrm{CI} / \mathrm{IIR} & 0.0278\end{array}$

As we can observe from the results of our computations, consistency ratio is calculated as 0.0278 , which well below the acceptable level of 0.1 . Therefore, we can confirm the overall survey. As we can observe from the results of Table 1, among three main factors, personal characteristics are the most important factors followed by managerial factors and environmental factors. In terms of personal factors, job satisfaction plays essential role on human resources development. In addition, our experts believe there must be a balance between job and technical skills. In other words, employees must be assigned to important jobs based on their job qualifications and educational background is an important factor. In terms of managerial factors, paying attention on continuous job improvement by receiving appropriate training is the most important factor followed by welfare facilities for employees and using a system of reward/punishment in organization. Finally, in terms of environmental factors, occupational safety is number one priority followed by organizational rules and regulations.

\section{Conclusion}

The primary aim of human resource productivity was to maximize effective usage of the most important factors of production, namely human resource. Findings from various theoretical studies have indicated that human resource productivity was an important issue for different organizations. This paper has presented a survey for identifying influencing factors on human resource productivity of IRIB, Mazandaran province. The survey has applied library studies and empirical investigations by getting experts' feedbacks and 17 factors have been determined. The implementation of AHP has indicated that personal characteristics are the most important factors followed by management related factors and environmental factors.

\section{References}

Allameh, S. M., Momeni, Z., \& Esfahani, Z. S. (2011). An assessment of the effect of information communication technology on human resource productivity of Mobarekeh steel complex in Isfahan (IRAN). Procedia Computer Science, 3, 1321-1326.

Beerkens, M. (2013). Facts and fads in academic research management: The effect of management practices on research productivity in Australia. Research Policy, 42(9), 1679-1693.

Bloom, N., \& Reenen, J. V. (2011). Human resource management and productivity. Handbook of labor economics, 4, 1697-1767.

Chlivickas, E. (2014). International cooperation and innovations for developing human resources system. Procedia - Social and Behavioral Sciences, 110, 276-283.

Göbel, C., \& Zwick, T. (2013). Are personnel measures effective in increasing productivity of old workers?. Labour Economics, 22, 80-93.

Jiang, K., Lepak, D. P., Han, K., Hong, Y., Kim, A., \& Winkler, A. L. (2012). Clarifying the construct of human resource systems: Relating human resource management to employee performance. Human Resource Management Review,22(2), 73-85.

Marco-Lajara, B., \& Úbeda-García, M. (2013). Human resource management approaches in Spanish hotels: An introductory analysis. International Journal of Hospitality Management, 35, 339-347.

Slavich, B., Cappetta, R., \& Giangreco, A. (2013). Exploring the link between human resource practices and turnover in multi-brand companies: The role of brand units' images. European Management Journal, 32(2), 177-189.

Zheng, S., \& Sun, Y. (2011). The analysis of human factors on grassland productivity in Western Songnen Plain. Procedia Environmental Sciences, 10(B), 1302-1307. 